\title{
Anti-infective Activities of Secondary Metabolites from Vitex pinnata
}

\author{
Nurkhalida Kamal ${ }^{1,2}$, Carol Clements ${ }^{1}$, Alexander I. Gray ${ }^{1}$, RuAngelie Edrada-Ebel ${ }^{1 *}$ \\ ${ }^{1}$ Strathclyde Institute of Pharmacy and Biomedical Sciences, University of Strathclyde, The John Arbuthnott Building, 161 Cathedral Street, Glasgow G4 \\ ORE, United Kingdom. ${ }^{2}$ Faculty of Bioresources \& Food Industry, Universiti Sultan Zainal Abidin, Kampus Tembila, 22200 Besut, Terengganu, Malaysia.
}

\begin{tabular}{l} 
ARTICLE INFO \\
\hline Article history: \\
Received on: $05 / 08 / 2015$ \\
Revised on: $11 / 09 / 2015$ \\
Accepted on: $15 / 11 / 2015$ \\
Available online: $26 / 01 / 2016$ \\
\hline Key words: Vitex pinnata; \\
steroids; flavones; \\
antitrypanosomal activity; \\
anti-mycobacterial activity.
\end{tabular}

\section{INTRODUCTION}

Plants play a pivotal role in drug discovery by producing various types of bioactive compounds including anticancer (Pezzuto, 1997), anti-diabetic (Marles and Farnsworth, 1995), anti-inflammatory (Nam, 2006), antiviral (Mukhtar et al., 2008) and also anti-protozoan neglected diseases drugs (Schmidt et al., 2012). Vitex pinnata is a woody plant which can be found in primary, secondary forests and savannahs. This species is under the genus Vitex with the family Lamiaceae (formerly was under family Verbenaceae). It can be found in Southeast Asia like in Malaysia, Indonesia, Thailand, Cambodia and Philippines (de Kok, 2008). Traditionally the young leaves of $V$. pinnata are used by Malay communities for antipyretic treatment and bark is used to treat gastric ulcer (Corner, 1951). Other previous study described the leaves of $V$. pinnata were applied on cuts and wounds (Ong and Nordiana, 1999). Human African trypanosomiasis (HAT) or sleeping sickness is one of neglected tropical diseases listed by World Health Organisation (WHO) (WHO, 2013a). It is a fatal vector-borne parasitic disease provoked by Trypanosoma brucei rhodesiense (T. $b$. rhodesiense) or Trypanosoma brucei gambiense (T. $b$. gambiense) and transmitted by the tsetse fly (Glossina spp.). This infectious disease happens specifically only in rural areas of subSaharan Africa (Simarro et al., 2011). Only few drugs have been

\footnotetext{
* Corresponding Author

Email:ruangelie.edrada-ebel@strath.ac.uk
}

used to treat this disease and these include suramin, pentamidin, melarsoprol and eflornithine and the combination of nifurtomox/eflornithine. Most of the drugs are old, having been discovered in the 1940s and 1950s, and also have adverse effects on patients. For this reason, mining and developing new HAT drugs from natural products is still crucial and indispensable (Jacobs et al., 2011). Tuberculosis (TB) is an infectious disease and the pathogen responsible for $\mathrm{TB}$ is Mycobacterium tuberculosis. TB still remains as a public health disease and infected millions of people each year. According to WHO report, $\mathrm{TB}$ is a second leading cause death after the human immunodeficiency virus (HIV) and estimated nearly 8.6 million new TB cases and 1.3 million TB deaths will occur in 2012 (WHO, 2013b). Although TB is curable, however the rise of multidrugresistance TB (MDR-TB) cases is very concerning which therefore require voluminous new anti MDR-TB drug candidates to be discovered to combat and eradicate this infectious diseases (WHO, $2013 b)$. The present study reports the chemical investigation of extract from $V$. pinnata. Previous phytochemical study revealed the isolation of ecdysteroids, which are pinnatasterone, 20hydroxyecdysone and turkesterone (Suksamrarn and Sommechai, 1993). Other study reported a new iridoid glucoside, pinnatoside and three known flavonoids namely viscioside, apigenin, and luteolin were isolated from the bark of $V$. pinnata (Ata et al., 2009). In this paper the isolation of secondary metabolites and its anti-infective activities against $T$. b. brucei and M. marinum of isolated compounds were described. 


\section{MATERIALS AND METHODS}

\section{General Equipment and Experimental Procedures}

The optical rotations of the compounds were measured on a 341 Polarimeter from PerkinElmer, Inc., USA. Analytical Thin Layer Chromatography (TLC) was performed on pre-coated TLC plates with normal silica gel 60 F254 and reverse phase TLC silica gel 60 RP-18 F254S (layer thickness 0.2 mm, Merck, Germany).

\section{Plant material}

Leaf parts of $V$. pinnata were collected from Marang Kuala Terengganu, situated approximately 500 kilometres northeast of Kuala Lumpur on the east coast of Peninsular Malaysia in September 2009. The plant was authenticated by Dr. Nashriyah Mat from Faculty of Bioresources and Food Industry, Universiti Sultan Zainal Abidin and voucher specimen was deposited (collection number VP 01).

\section{Extraction and Isolation}

The ground leaves of $V$. pinnata $(1 \mathrm{~kg})$ were extracted in a Soxhlet apparatus at $40^{\circ} \mathrm{C}$ by utilising three different solvents based on their polarity. The extraction was started with $n$-hexane followed by ethyl acetate then methanol with solvent volumes of 7.5 L each for 72 hours.

Later the extracts were concentrated in vacuo by using rotary evaporator (BUCHI Labortechnik AG, Switzerland) at $40^{\circ} \mathrm{C}$ and the yield was 6.33g ( $n$-hexane extract), 6.5g (ethyl acetate extract) and $5.2 \mathrm{~g}$ (methanol extract). All dried extracts were stored at $-20^{\circ} \mathrm{C}$ freezer. Fractionation of the $n$-hexane extract $(6.33 \mathrm{~g})$ was accomplished by using Medium Pressure Liquid Chromatography (MPLC).

Linear gradient elution was employed with hexane (A) and ethyl acetate (B) as solvents at a flow rate of $100 \mathrm{ml} / \mathrm{min}$. Prepacked VersaPak silica cartridge (particle size 20-45 $\mu \mathrm{m}$, diameter and length $40 \times 150 \mathrm{~mm}$ ) from Supelco was used in this run. $100 \%$ A was run for $5 \mathrm{~min}$ (isocratic) followed by $100 \%$ A to $100 \% \mathrm{~B}$ for $20 \mathrm{~min}$ (gradient) then with $100 \% \mathrm{~B}$ for the last $5 \mathrm{~min}$ (isocratic).

The run time was $30 \mathrm{~min}$ in total. For the first and last 5 min of the run, the fractions were collected for every $100 \mathrm{ml}$ and followed by $50 \mathrm{ml}$ volume fractions for $20 \mathrm{~min}$ resulting to 50 fractions. Fractions with similar TLC profiles were pooled together yielding 28 fractions. Fraction 12 contained a mixture of two compounds assigned as $\mathbf{1}$ (15mg).

Fraction 13 was further subjected to MPLC over a a prepacked VersaPak silica cartridge (particle size 20-45 $\mu \mathrm{m}$, diameter and length $23 \times 53 \mathrm{~mm}$ ) utilising an isocratic gradient system with $80 \%$ hexane and $20 \%$ ethyl acetate for $30 \mathrm{~min}$ at a flow rate of 20 $\mathrm{ml} / \mathrm{min}$. Fraction 13 afforded six sub-fractions and gave one pure compound 2 (20 mg). Fraction 16 afforded one major compound 3 (4 mg). Fraction 19 afforded the major compound 4 (130mg) by crystallisation after washing with mixtures of hexane and methanol.

\section{NMR Instrumentation}

One and two dimensional Nuclear Magnetic Resonance (NMR) experiments were measured in Strathclyde Institute of Pharmacy and Biomedical Sciences by using $400 \mathrm{MHz}$ on an AS400 JEOL NMR instrument (Tokyo, Japan). All isolated samples were dissolved in $650 \mu \mathrm{l}$ of deuterated chloroform $\left(\mathrm{CDCl}_{3}\right)$.

\section{HR-LCMS analysis}

In High Resolution-Liquid Chromatography Mass Spectrometry (HR-LCMS) analysis, all samples were dissolved in $\mathrm{MeOH}$ HPLC grade to give final concentration of $1 \mathrm{mg} / \mathrm{ml}$. HRLCMS analysis was carried out using a Accela 600 High Performance Liquid Chromatography (HPLC) pump with Accela autosampler and UV/Vis detector (Thermo Scientific, Bremen, Germany) and Orbitrap Exactive mass spectrometer (Thermo Fisher Scientific Inc, Hemel Hempstead UK). A reversed phase silica C18 HPLC column, 75.0 x $3.0 \mathrm{~mm}^{2}$ (Hichrom Limited, UK) with particle size of $5 \mu \mathrm{m}$, pore size $100{ }^{\circ} \mathrm{A}$ was used. The approximate pressure was at 37 bar while the temperature was maintained at $22{ }^{\circ} \mathrm{C}$. The mobile phase consisted of purified water (A) and acetonitrile (B) with $0.1 \%$ formic acid in each solvent. The samples were eluted on a linear gradient of $90 \% \mathrm{~A}$ and $10 \% \mathrm{~B}$ to $100 \% \mathrm{~B}$ for $30 \mathrm{~min}$ and changed to isocratic mode for $5 \mathrm{~min}$ before decreasing back to $10 \%$ of $\mathrm{B}$ for $1 \mathrm{~min}$. Then the column was re-equilibrated with $10 \%$ of $\mathrm{B}$ for $9 \mathrm{~min}$ before the next sample injection. The flow rate used in this method was $300 \mu \mathrm{l} / \mathrm{min}$ and the injection volume was $10 \mu \mathrm{l}$.

\section{GCMS Analysis}

Sample $(1 \mu \mathrm{l})$ was injected into the the Gas Chromatography Mass Spectrometry (GCMS) (Focus GC-DSQ2) system from Thermo Fisher Scientific (Bremen, Germany) using with $30 \mathrm{~m}$ long, $0.25 \mathrm{~mm}$ i.d., and $0.25 \mu \mathrm{m}$ film thickness InertCap 1 MS capillary column from GL Sciences (Japan). The oven temperature was set at $80^{\circ} \mathrm{C}$ for 1 minute and the temperature was increased at a rate of $15^{\circ} / \mathrm{min}$ until it reached to $200^{\circ} \mathrm{C}$ and was maintained for $15 \mathrm{~min}$. Then the temperature was again increased at a rate of $5^{\circ} \mathrm{C} / \mathrm{min}$ until the final temperature of $320^{\circ} \mathrm{C}$ (held for $10 \mathrm{~min}$ ). The base temperature of the split/splitless (SSL) was $250^{\circ} \mathrm{C}$. The mode was splitless. The split flow was on at 15 $\mathrm{mL} / \mathrm{min}$. The splitless time was 1 minute. The carrier method was set to constant flow. The initial value was $1.50 \mathrm{~mL} / \mathrm{min}$ and the initial time was 1 minute. The MS transfer line was maintained at a temperature of $320^{\circ} \mathrm{C}$. The source temperature of the DSQ II mass spectrometer was set to $250^{\circ} \mathrm{C}$. The mass range used was 50.0-800.0.

\section{Anti-infective assays}

The in vitro antitrypanosomal and antimycobacterial activities were examined according to the standard protocols previously published (Viegelmann et al., 2014).

\section{RESULT AND DISCUSSION}

The substance $\mathbf{1}$ was observed as a white powder. From the GCMS result, it showed two peaks at 19:23 and 19:53 minutes 
with the molecular ion peaks at $\mathrm{m} / \mathrm{z} 412.51[\mathrm{M}]^{+}$and $414.51[\mathrm{M}]^{+}$, respectively. Online GCMS NIST library database suggested this fraction is a mixture of two compounds. GCMS spectrum at $\mathrm{m} / \mathrm{z}$ 414.51 suggested the compound is $\beta$-sitosterol 1a, with the molecular formula $\mathrm{C}_{29} \mathrm{H}_{50} \mathrm{O}$ while at $m / z, 412.51$ is stigmasterol $\mathbf{1 b}$ with the molecular formula $\mathrm{C}_{29} \mathrm{H}_{48} \mathrm{O}$. The $\mathrm{HMQC}$ spectrum was done to confirm the identity of the individual compounds in each of the mixture which were elucidated as $\beta$-sitosterol and stigmasterol by observing the specific signals at positions C-22 and $\mathrm{C}-23$.

In the HMQC spectrum of stigmasterol the chemical shifts at positions C-22 and C-23 are 138.0 and $129.2 \mathrm{ppm}$, respectively which suggested an alkene group while in $\beta$-sitosterol, chemical shift signals at C-22 and C-23 were at 34.0 and 26.1 ppm, respectively for an alkyl group. Based on comparison to ${ }^{13} \mathrm{C}$ NMR data of $\mathbf{1 a}$ and $\mathbf{1 b}$ to the previous literatures (Alam et al., 1996; Mahato and Kundu, 1994) (Table 1) supported that compound $\mathbf{1 a}$ and $\mathbf{1 b}$ is a mixture of $\beta$-sitosterol and stigmasterol.

Table 1: ${ }^{13} \mathrm{C}$ NMR data of $\beta$-sitosterol (1a) and stigmasterol (1b) in Chloroform- $d$

\begin{tabular}{|c|c|c|c|c|}
\hline Carbon & 1a & $\begin{array}{l}\beta \text {-sitosterol } \\
\text { (Alam et al., } \\
\text { 1996) in } \\
\text { Chloroform- } d\end{array}$ & 1b & $\begin{array}{c}\text { Stigmasterol } \\
\text { (Mahato and } \\
\text { Kundu, 1994) in } \\
\text { Chloroform- } d\end{array}$ \\
\hline Position & $\delta_{\mathrm{C}}$ & $\delta_{\mathrm{C}}$ & $\delta_{\mathrm{C}}$ & $\delta_{\mathrm{C}}$ \\
\hline 1 & 37.4 & 37.3 & 37.1 & 37.3 \\
\hline 2 & 31.9 & 31.9 & 31.6 & 31.7 \\
\hline 3 & 71.8 & 71.9 & 71.8 & 71.9 \\
\hline 4 & 42.3 & 42.3 & 41.5 & 42.3 \\
\hline 5 & 140.3 & 140.8 & 140.3 & 140.8 \\
\hline 6 & 121.7 & 121.8 & 121.7 & 121.8 \\
\hline 7 & 31.7 & 31.7 & 31.7 & 32.1 \\
\hline 8 & 32.0 & 32.0 & 32.0 & 32.0 \\
\hline 9 & 50.1 & 50.2 & 50.1 & 50.2 \\
\hline 10 & 36.5 & 36.6 & 36.7 & 36.6 \\
\hline 11 & 21.1 & 21.2 & 20.8 & 21.2 \\
\hline 12 & 39.6 & 39.8 & 39.6 & 39.8 \\
\hline 13 & 42.3 & 42.4 & 42.3 & 42.4 \\
\hline 14 & 56.7 & 56.8 & 56.7 & 56.8 \\
\hline 15 & 24.3 & 24.4 & 24.3 & 24.4 \\
\hline 16 & 28.6 & 28.3 & 28.6 & 28.3 \\
\hline 17 & 55.9 & 56.1 & 55.9 & 56.1 \\
\hline 18 & 11.6 & 11.9 & 11.6 & 11.9 \\
\hline 19 & 19.4 & 19.5 & 19.2 & 19.1 \\
\hline 20 & 36.2 & 36.2 & 40.1 & 40.6 \\
\hline 21 & 18.8 & 18.9 & 20.5 & 20.0 \\
\hline 22 & 34.0 & 34.0 & 138.0 & 138.4 \\
\hline 23 & 26.1 & 26.2 & 129.2 & 129.2 \\
\hline 24 & 45.8 & 46.0 & 51.1 & 51.3 \\
\hline 25 & 29.2 & 29.2 & 32.0 & 34.0 \\
\hline 26 & 19.8 & 19.9 & 19.0 & 18.9 \\
\hline 27 & 19.0 & 19.1 & 21.2 & 21.3 \\
\hline 28 & 23.1 & 23.1 & 25.4 & 25.5 \\
\hline 29 & 12.0 & 12.1 & 12.0 & 12.1 \\
\hline
\end{tabular}

Compound 2 was obtained as white needles, m.p. $427^{\circ} \mathrm{C}$. ESI-MS peak in the positive mode was found at $\mathrm{m} / \mathrm{z} 329.1026$ $[\mathrm{M}+\mathrm{H}]^{+}$(base peak) which revealed a molecular weight of 328.32 $\mathrm{g} / \mathrm{mol}$ and a molecular formula of $\mathrm{C}_{18} \quad \mathrm{H}_{16} \mathrm{O}_{6}$. Consequently, compound 2 had 11 degree of unsaturation. The ${ }^{1} \mathrm{H}$ NMR spectrum of 2 (Table 2) displayed a singlet signal at $\delta 12.65$ due to the strongly hydrogen bonded phenolic hydroxyl moiety. The presence of two doublet signals at $\delta_{\mathrm{H}} 6.44(\mathrm{~d}, J=2)$ and $\delta 6.35(\mathrm{~d}, J=2)$ were characteristic of two meta-related $\mathrm{H}-6$ and $\mathrm{H}-8$ as in a 5,7 disubstituted A-ring flavonoid. In the $\mathrm{B}$ ring system, two sets of symmetric proton doublet signals at $\delta 8.07(2 \mathrm{H}, \mathrm{d}, J=9)$ and 7.02 $(2 \mathrm{H}, \mathrm{d}, J=9)$ were detected for an AA' BB' system which indicated that C-4' was substituted. In addition, the ${ }^{1} \mathrm{H}$ NMR spectrum of this compound exhibited three singlets at $\delta_{\mathrm{H}} 3.89,3.87$ and 3.85 showing the existence of three methoxyl groups. By comparing the data with previous literature (Rossi et al., 1997), the compound 2 was identified as 5-hydroxy-3, 7, 4'-trimethoxyflavone previously isolated from Aniba species. Compound $\mathbf{3}$ was obtained as white needles, m.p. $381^{\circ} \mathrm{C}$. The ESI-MS spectrum showed a molecular ion at negative mode with $m / z$ 297.2434 [M-H] ${ }^{-}$suggested a molecular formula of $\mathrm{C}_{19} \mathrm{H}_{18} \mathrm{O}_{7}$. The ${ }^{1} \mathrm{H}$ NMR spectrum (Table 2) showed of two methoxy signals at $\delta_{\mathrm{H}} 3.88$ and 3.89. One downfield singlet at $\delta_{\mathrm{H}} 12.80$ assigned to a phenolic hydroxyl group. The ${ }^{1} \mathrm{H}$ NMR spectrum of compound $\mathbf{3}$ was found to be similar to spectrum compound $\mathbf{2}$ except that compound $\mathbf{3}$ showed additional singlet peak at $\delta_{\mathrm{H}} 6.58$ suggested its position at C-3. In the A ring, $\mathrm{AB}$ system was assigned to two doublet protons $(\mathrm{H}-6$ and $\mathrm{H}-8)$ at $\delta_{\mathrm{H}} 6.37$ and 6.48 with typical meta coupling constant of $J=2.2 \mathrm{~Hz}$. In the B ring system, two sets of symmetric proton signals $\delta 7.84(2 \mathrm{H}, \mathrm{d}, J=9)$ and $7.01(2 \mathrm{H}, \mathrm{d}, J=9)$ were detected for an AA' BB' system which indicated that C-4' was substituted. The structure of $\mathbf{3}$ was identified as 5-hydroxy-7, 4'-dimethoxyflavone based on comparison to the previous published data (Kolak et al., 2009). Compound 4 was obtained as white crystalline needles, m.p. $473^{\circ} \mathrm{C}$. A molecular formula of $\mathrm{C}_{19} \mathrm{H}_{18} \mathrm{O}_{7}$ was deduced by ESI-MS with molecular ion peak at $m / z, 359.1134[\mathrm{M}+\mathrm{H}]^{+}$(base peak) with 11 degrees of unsaturation.

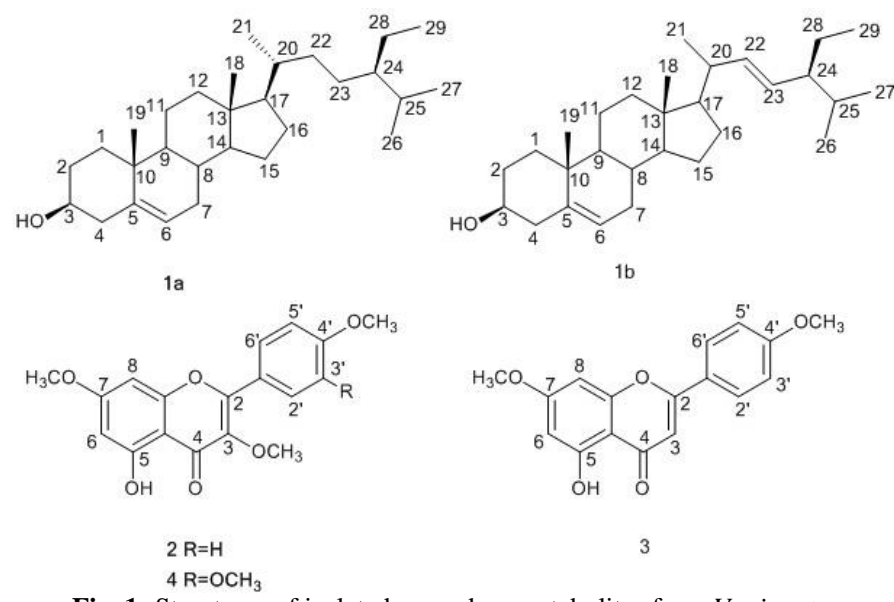

Fig. 1: Structures of isolated secondary metabolites from $V$. pinnata

The ${ }^{1} \mathrm{H}$ NMR spectrum (Table 3 ) showed four methoxy signals at $\delta_{\mathrm{H}} 3.86,3.88,3.96$ and 3.97. One downfield singlet at $\delta_{\mathrm{H}}$ 12.64 was assigned to a phenolic hydroxyl group. In the A ring, AB system was assigned to two doublet protons (H-6 and H-8) at $\delta_{\mathrm{H}} 6.36$ and 6.45 with a typical meta coupling constant of $J=2.2$ $\mathrm{Hz}$. 
Table 2: ${ }^{13} \mathrm{C}$ NMR data of 5-hydroxy-3, 7, 4'-trimethoxyflavone (2) and 5-hydroxy-7, 4'-dimethoxyflavone (3) in Chloroform- $d$.

\begin{tabular}{|c|c|c|c|c|}
\hline Position & 2 & $\begin{array}{l}\text { 5-hydroxy-3, 7, 4'-trimethoxyflavone } \\
\text { (Rossi et al., 1997) in Chloroform-d }\end{array}$ & 3 & $\begin{array}{l}\text { 5-hydroxy-7, 4'-dimethoxyflavone } \\
\text { (Kolak et al., 2009) in Chloroform- } d\end{array}$ \\
\hline & $\delta_{\mathrm{H}}(J \mathrm{~Hz})$ & $\delta_{\mathrm{H}}(J \mathrm{~Hz})$ & $\delta_{\mathrm{H}}(J \mathrm{~Hz})$ & $\delta_{\mathrm{H}}(J \mathrm{~Hz})$ \\
\hline 3 & & & $6.58, \mathrm{~s}$ & $6.58, \mathrm{~s}$ \\
\hline 6 & $6.35, \mathrm{~d}(J=2)$ & $6.33, \mathrm{~d}(J=2)$ & $6.36, \mathrm{~d}(J=2.2)$ & $6.37, \mathrm{~d}(J=2.4)$ \\
\hline 8 & $6.44, \mathrm{~d}(J=2)$ & $6.43, \mathrm{~d}(J=2)$ & $6.48, \mathrm{~d}(J=2.2)$ & $6.48, \mathrm{~d}(J=2.4)$ \\
\hline $2^{\prime}$ and 6 ' & $8.07, \mathrm{~d}(J=9)$ & $8.07, \mathrm{~d}(J=9)$ & $7.84, \mathrm{~d}(J=9.0)$ & $7.85, \mathrm{~d}(J=9.0)$ \\
\hline $3^{\prime}$ and $5^{\prime}$ & $7.02, \mathrm{~d}(J=9)$ & $7.0, \mathrm{~d}(J=9)$ & $7.01, \mathrm{~d}(J=9.0)$ & $7.02, \mathrm{~d}(J=9.0)$ \\
\hline $3-\mathrm{OCH}_{3}$ & $3.87, \mathrm{~s}$ & $3.84, \mathrm{~s}$ & $3.89, \mathrm{~s}$ & $3.84, \mathrm{~s}$ \\
\hline $7-\mathrm{OCH}_{3}$ & $3.89, \mathrm{~s}$ & $3.84, \mathrm{~s}$ & $3.88, \mathrm{~s}$ & $3.84, \mathrm{~s}$ \\
\hline $4^{\prime}-\mathrm{OCH}_{3}$ & $3.85, \mathrm{~s}$ & $3.84, \mathrm{~s}$ & $12.80, \mathrm{~s}$ & $12.80, \mathrm{~s}$ \\
\hline $5-\mathrm{OH}$ & $12.65, \mathrm{~s}$ & $12.6, \mathrm{~s}$ & & \\
\hline
\end{tabular}

Table 3: ${ }^{13} \mathrm{C}$ NMR data of 5-hydroxy-3,3',4',7-tetramethoxyflavone (4) in Chloroform- $d$.

\begin{tabular}{|c|c|c|}
\hline \multirow[t]{2}{*}{ Position } & 4 & 5-hydroxy-3,3',4',7-tetramethoxyflavone (Li et al., 2006) in DMSO- $d_{6}$ \\
\hline & $\overline{\delta \mathrm{H}}(J \mathrm{~Hz})$ & $\delta \delta_{\mathrm{H}}(J \mathrm{~Hz})$ \\
\hline 6 & $6.36, \mathrm{~d}(J=2.2)$ & $6.39, \mathrm{~d}(J=2.2)$ \\
\hline 8 & $6.45, \mathrm{~d}(J=2.2)$ & 6.80. d $(J=2.2)$ \\
\hline 2 ' & $7.69, \mathrm{~d}(J=2.0)$ & 7.67, d $(J=2.0)$ \\
\hline 5 , & $6.99, \mathrm{~d}(J=8.9)$ & 7.17, d $(J=9.0)$ \\
\hline 6' & $7.73, \mathrm{dd}(J=8.9,2.0)$ & $7.74, \mathrm{dd}(J=9.0,2.0)$ \\
\hline 3- $\mathrm{OCH}_{3}$ & $3.86, \mathrm{~s}$ & $3.83, \mathrm{~s}$ \\
\hline 7- $\mathrm{OCH}_{3}$ & $3.88, \mathrm{~s}$ & $3.87, \mathrm{~s}$ \\
\hline 3'- $\mathrm{OCH}_{3}$ & $3.96, \mathrm{~s}$ & $3.87, \mathrm{~s}$ \\
\hline 4'- $\mathrm{OCH}_{3}$ & 3.97, s & $3.88, \mathrm{~s}$ \\
\hline 9-OH & $12.64, \mathrm{~s}$ & $12.62, \mathrm{~s}$ \\
\hline
\end{tabular}

Compound 1a and 1b, 2, 3 and $\mathbf{4}$ showed moderate antitrypanosomal activity with MIC values of $6.25 \mu \mathrm{g} / \mathrm{ml}, 19.0$, 21.0 and $17.0 \mu \mathrm{M}$. However no activity was observed in all isolated compounds against $M$. marinum (Table 4). Previous study reported that compound 4 was inactive against $T . b$. rhodesiense and $T$. cruzi $\left(\mathrm{IC}_{50}>80 \mu \mathrm{M}\right)$ however showed adequate antileismanial activity against Leishmania donovani with $\mathrm{IC}_{50}$ value of $21.77 \mu \mathrm{M}$ (Tasdemir et al., 2006).

Table 4: Summary of anti-infective activities of isolated compounds from $V$. pinnata.

\begin{tabular}{ccc}
\hline Compounds & $\begin{array}{c}\text { Antitrypanosomal activity } \\
\text { against } \boldsymbol{T} \text {. } \boldsymbol{b} \text {. brucei, MIC } \\
(\boldsymbol{\mu M})\end{array}$ & $\begin{array}{c}\text { Anti-mycobacterial } \\
\text { activity against } \boldsymbol{M} . \\
\text { marinum } \text { MIC }(\boldsymbol{\mu M})\end{array}$ \\
\hline $\mathbf{1}$ & $6.25 \mu \mathrm{g} / \mathrm{ml}$ & $>100$ \\
$\mathbf{2}$ & $19.0 \pm 3.5$ & $>100$ \\
$\mathbf{3}$ & $21.0 \pm 4.1$ & $>100$ \\
$\mathbf{4}$ & $17.0 \pm 2.3$ & $>100$ \\
$\begin{array}{c}\text { Suramin } \\
\text { Gentamycin }\end{array}$ & $0.11 \pm 0.0$ & $13.48 \pm 0.0$ \\
\hline
\end{tabular}

Tumor necrosis factor- $\alpha$ (TNF- $\alpha)$ is a group of cytokines that involved systemic inflammatory reaction. Previous report describes the level of TNF- $\alpha$ was increased in the sera of bacterial, viral, and parasitic-infected patients including malaria and leishmaniasis (Barral-Netto et al., 1991; Scuderi et al., 1986; Shaffer et al., 1991).

The level of TNF- $\alpha$ in serum of T. b. gambiense-infected patient also corresponding with the disease severity (OkomoAssoumou et al., 1995). Other finding also reported the level of TNF- $\alpha$ was high in patient with late-stage of $T$. $b$. gambiense infection and was declined dramatically after treatment with melarsoprol (Rhind et al., 1997). Traditionally, Malay community used leaves of $V$. pinnata to treat inflammation including fever and wounds (Burkill, 1966; Ong and Nordiana, 1999) and based from these evidences suggested the anti-inflammatory response in treating fever and wounds is possibly from compound 2, 3 and 4 which exhibited moderate antitrypanosomal activity against $T$. $b$. brucei.

\section{CONCLUSIONS}

In conclusion, this finding reported that compound $\mathbf{2}, \mathbf{3}$ and 4 were isolated efficiently for the first time from $V$. pinnata by using MPLC. In this study as well reported a moderate antitrypanosomal activity of these compounds against $T . b$. brucei for the first time.

\section{ACKNOWLEDGEMENTS}

We thank Ministry of Higher Education Malaysia for a scholarship for Nurkhalida Kamal

\section{REFERENCES}

Alam MS, Chopra N, Ali M, Niwa M. Oleanen and stigmasterol derivatives from Ambroma augusta. Phytochemistry, 1996; 41:1197-1200.

Ata A, Mbong N, Iverson CD, Samarasekera R. Minor chemical constituents of Vitex pinnata. Natural product communications, 2009; 4:1.

Barral-Netto M, Badaró R, Barral A, Almeida RP, Santos SB, Badaró F, Pedral-Sampaio D, Carvalho EM, Falcoff E, Falcoff R. Tumor Necrosis Factor (Cachectin) in Human Visceral Leishmaniasis. Journal of Infectious Diseases, 1991; 163:853-857.

Burkill IH. 1966. A Dictionary of the Economic Products of the Malay Peninsula. Ministry of Agriculture Co-operatives: Kuala Lumpur 2280.

Corner EJH. 1951. Wayside trees of Malaya. Singapore Govern: Singapore. de Kok R. The genus Vitex (Labiatae) in the flora Malesiana region, excluding New Guinea. Kew Bulletin, 2008; 63:17-40. 
Jacobs RT, Nare B, Phillips MA. State of the art in African trypanosome drug discovery. Current topics in medicinal chemistry, 2011; 11:1255.

Kolak U, Hacibekıroğlu I, Öztürk M, Özgökçe F, Topçu G, Ulubelen A. Antioxidant and anticholinesterase constituents of Salvia poculata. Turkish Journal of Chemistry, 2009; 33.

Li S, Lo C-Y, Ho C-T. Hydroxylated polymethoxyflavones and methylated flavonoids in sweet orange (Citrus sinensis) peel. Journal of agricultural and food chemistry, 2006; 54:4176-4185.

Mahato SB, Kundu AP. 13C NMR Spectra of pentacyclic triterpenoids--a compilation and some salient features. Phytochemistry, 1994; 37:1517-1575.

Malan E, Roux DG. Flavonoids from Distemonanthus benthamianus Baillon. Methoxylated flavones and inter-relationships of benthamianin, a [2]benzopyrano[4,3-b][1]benzopyran. Journal of the Chemical Society, Perkin Transactions 1, 1979:2696-2703.

Marles RJ, Farnsworth NR. Antidiabetic plants and their active constituents. Phytomedicine, 1995; 2:137-189.

Mukhtar M, Arshad M, Ahmad M, Pomerantz RJ, Wigdahl B, Parveen Z. Antiviral potentials of medicinal plants. Virus Research, 2008; 131:111-120.

Nam N-H. Naturally occurring NF-kB inhibitors. Mini reviews in medicinal chemistry, 2006; 6:945-951.

Okomo-Assoumou MC, Daulouede S, Lemesre J-L, N'ZilaMouanda A, Vincendeau P. Correlation of High Serum Levels of Tumor Necrosis Factor- $\alpha$ with Disease Severity in Human African trypanosomiasis. The American Journal of Tropical Medicine and Hygiene, 1995; 53:539-543.

Ong H, Nordiana M. Malay ethno-medico botany in Machang, Kelantan, Malaysia. Fitoterapia, 1999; 70:502-513.

Pezzuto JM. Plant-derived anticancer agents. Biochemical pharmacology, 1997; 53:121-133.

Rhind SG, Sabiston BH, Shek PN, Buguet A, Muanga G, Stanghellini A, Dumas M, Radomski MW. Effect of Melarsoprol Treatment on Circulating IL-10 and TNF- $\alpha$ Levels in Human African Trypanosomiasis. Clinical Immunology and Immunopathology, 1997; 83:185-189.

Rossi MH, Yoshida M, Soares Maia JG. 1997. Neolignans, styrylpyrones and flavonoids from an Aniba species. 1263-1269 p.
Schmidt T, Khalid S, Romanha A, Alves T, Biavatti M, Brun R, Da Costa F, De Castro S, Ferreira V, De Lacerda M. The potential of secondary metabolites from plants as drugs or leads against protozoan neglected diseases-Part II. Curr. Med. Chem, 2012; 19:21762228 .

Scuderi P, Lam K, Ryan K, Petersen E, Sterling K, Finley P, Ray CG, Slymen D, Salmon S. Raised serum levels of tumour necrosis factor in parasitic infections. The Lancet, 1986; 328:1364-1365.

Shaffer N, Grau GE, Hedberg K, Davachi F, Lyamba B, Hightower AW, Breman JG, Nguyen-Dinh P. Tumor Necrosis Factor and Severe Malaria. Journal of Infectious Diseases, 1991; 163:96101.

Simarro PP, Diarra A, Postigo JAR, Franco JR, Jannin JG. The human African trypanosomiasis control and surveillance programme of the World Health Organization 2000-2009: the way forward. PLoS neglected tropical diseases, 2011; 5:e1007.

Suksamrarn A, Sommechai C. Ecdysteroids from Vitex pinnata. Phytochemistry, 1993; 32:303-306.

Tasdemir D, Kaiser M, Brun R, Yardley V, Schmidt TJ, Tosun F, Rüedi P. Antitrypanosomal and antileishmanial activities of flavonoids and their analogues: in vitro, in vivo, structure-activity relationship, and quantitative structure-activity relationship studies. Antimicrobial agents and chemotherapy, 2006; 50:1352-1364.

Viegelmann C, Parker J, Ooi T, Clements C, Abbott G, Young L, Kennedy J, Dobson A, Edrada-Ebel R. Isolation and Identification of Antitrypanosomal and Antimycobacterial Active Steroids from the Sponge Haliclona simulans. Marine Drugs, 2014; 12:2937-2952.

WHO. 2013a. Sustaining the drive to overcome the global impact of neglected tropical diseases: second WHO report on neglected tropical diseases: summary.

WHO. 2013b. Global tuberculosis report 2013. World Health Organization: Geneva, Switzerland.

\section{How to cite this article:}

Kamal N, Clements C, Gray AI, Edrada-Ebel R. Anti-infective Activities of Secondary Metabolites from Vitex pinnata. J App Pharm Sci, 2016; 6 (01): 102-106. 